\title{
Evaluation of Coconut Germplasm in Weligama and Matara area of the Southern Province of Sri Lanka for Resistance to Weligama Coconut Leaf Wilt Disease
}

\author{
S. A. C. N. Perera, H. M. N. B. Herath, H. T. R. Wijesekera, W. G. R. Subhathma and \\ W. A. T. L. Weerakkody \\ Coconut Research Institute, Lunuwila 61150. Sri Lanka
}

Corresponding author: S. A. C. N. Perera

Genetics and Plant Breeding Division, Coconut Research Institute, Lunuwila, 61150

chandrikaperera2003@yahoo.com

\begin{abstract}
Weligama Coconut Leaf Wilt Disease has been reported to infect the coconut palms in Southern Sri Lanka. Intra-cellular pathogen phytoplasma has been identified as the causal organism of this disease. So far there have been no known control methods to cure diseases caused by intra-cellular pathogens. Integration of resistant varieties into management programmes has been identified as a viable option in management strategies of such diseases. For this, it is essential to identify the resistance of available genetic resources. This study was carried out in the Weligama and Matara area of Southern Sri Lanka to screen the coconut germplasm for resistance to Weligama Coconut Leaf Wilt Disease. Infected and healthy palms were differentiated using symptomatology; flaccidity of leaves, yellowing of leaves and marginal necrosis of leaflets. Sri Lanka Tall, Sri Lanka Green and yellow dwarfs, Gon thembili tall and king coconut were among the main coconut forms studied. Out of them Sri Lanka Green Dwarf recorded a high level of resistance (98\%). Within the Sri Lanka Yellow dwarf and Gon thembili tall, certain individual genotypes were observed to be resistant while king coconut was identified to be susceptible. The most popular commercial coconut variety, Sri Lanka tall was highly susceptible to the disease although there were certain individual genotypes which were resistant. Although Sri Lanka Green dwarf has not so far been viable as a commercial coconut cultivar the presence of resistant genes within the coconut germplasm was recognized as a great advantage in breeding coconuts for resistance to Weligama Coconut Leaf Wilt Disease.
\end{abstract}




\section{INTRODUCTION}

Weligama Coconut Leaf Wilt Disease (WCLWD) that has been reported in Southern Sri Lanka is now known to be caused by Phytoplasma (Perera et al. 2012). Phytoplasma are intracellular organisms and thus are obligatory parasites. The diseases caused by phytoplasma in coconut as well as in other crops are practically incurable. The repercussions of incurable diseases are much higher in perennial tree crops such as coconuts compared to annuals and therefore adopting the best disease control/ management methods is vital.

Currently, the most viable method of managing phytoplasma diseases is to cultivate resistant varieties. The resistance of such varieties is genetically governed. These varieties should be identified within the infected area itself to ensure that the resistance is due to genes and not the environment lacking the innoculum. The availability of a broad genetic diversity of the germplasm of a crop species within the infected area is highly advantageous in finding one or a few resistant varieties. Incidentally, the Southern Province of Sri Lanka (more specifically, Galle and Matara districts) is rich in coconut diversity, harbouring many of the coconut varieties and forms so far identified in Sri Lanka (Liyanage, 1958; Ekanayake et al. 2010). However, the systematic plantations even in the Southern province are generally planted with commonly grown commercial coconut cultivars such as Sri Lanka tall and are lacking in diverse coconut material. Home gardens on the other hand, especially in the Southern part of the island consist of much diverse coconut genetic material including many of the indigenous coconut varieties and forms found in Sri Lanka.

Flaccidity of the leaves, marginal necrosis of leaflets and yellowing of leaves, especially the mid whorl yellowing are the prominent symptoms of WCLWD with fungal leaf rot superimposed on the palms weakened by WCLWD (Wijesekara et al. 2008). If certain palms remain healthy while some others are diseased in the same environment under similar innoculum pressure, the healthy palms can be hypothesized to possess the genes for resistance to the disease. Covering the entire available coconut diversity in the area is important to identify the total pool of coconut varieties and forms which is resistant to WCLWD.

Considering the above factors an extensive field survey was carried out in the Weligama and Matara area of the Southern Province of Sri Lanka, where the disease incidence is very high with the objective of identifying coconut varieties which are resistant to WCLWD.

\section{MATERIALS AND METHODS}

A field survey was conducted in the area from Weligama to Matara in the Southern Province of Sri Lanka, to identify resistant coconut varieties. The target coconut holdings were the home gardens rather than plantations.

The coconut form Sri Lanka Green Dwarf (SLGD) was given special reference in this field survey because this particular variety has been reported to be resistant to another phytoplasma associated disease, lethal yellowing which is found in the Caribbean.

Healthy and diseased palms were differentiated with WCLWD symptoms flaccidity, marginal necrosis of leaflets and yellowing of fronds. Other factors that may cause similar symptoms, such as shade and varietal traits for flaccidity and different causes for yellowing were also considered in distinguishing healthy and disease infected palms. 
In total 124 home gardens were surveyed from Weligma to Matara in Southern Sri Lanka and the resistant sources were documented in 05 different forms of coconut most of which are included in the coconut classification in Sri Lanka.

\section{RESULTS AND DISCUSSION}

Coconut varieties Sri Lanka tall (SLT) and Gon thembili tall (GTT) and several other phenotypes belonging to variety Typica, Sri Lanka Green dwarf (SLGD) (Plates 01 and 02) including Green dwarf 'Murusi' form (Ekanayake et al. 2010) and Sri Lanka Yellow dwarf (SLYD) belonging to variety Nana and King coconut (KC) from Intermediate coconut variety Aurantiaca were evaluated in the survey for resistance to WCLWD.

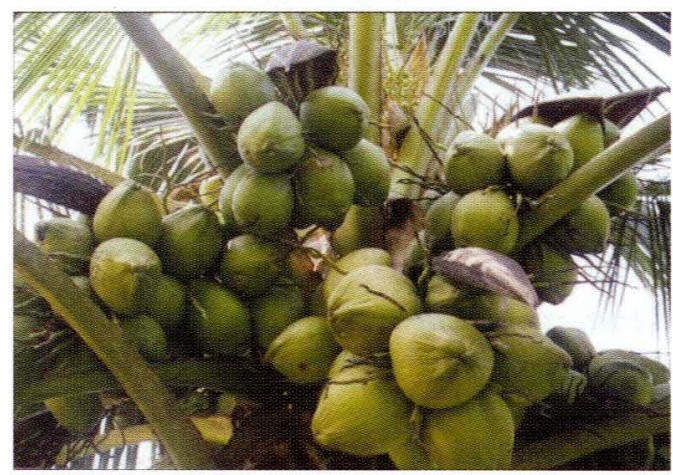

Plate 01: Crown of a resistant Sri Lanka Green Dwarf (Murusi) palm

\section{Resistance of different forms and varieties}

Of all the coconut forms assessed, Sri Lanka green dwarf including its 'Murusi' coconut form displayed a very high degree of resistance to WCLWD. Ninety eight percent of the palms evaluated from a total of 250 palms were identified to be healthy amidst the disease infected palms (Table 01). Consequently, Sri Lanka Green dwarf was identified as a coconut form with a very high degree of resistance to WCLWD.

The Nana coconut form, SLYD showed a fair degree of resistance to WCLWD but not as high as that of Sri Lanka Green dwarf. Out of a total of 27 SLYD coconut palms evaluated, 18 were observed to be disease free recording the second highest degree of resistance to WCLWD.

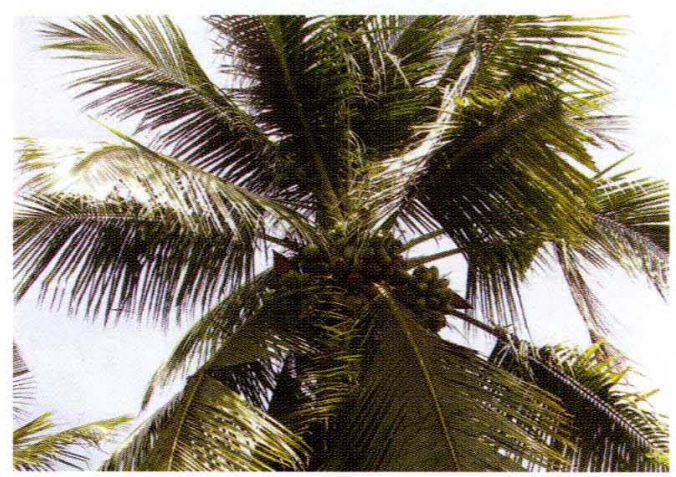

Plate 02: Resistant Sri Lanka Green Dwarf palm

Table 01: Percentages of resistance of the studied coconut forms

\begin{tabular}{lccc}
\hline Coconut form & Number of palms & $\begin{array}{c}\text { Number of } \\
\text { resistant palms }\end{array}$ & \% resistance \\
\hline $\begin{array}{l}\text { Sri Lanka } \\
\text { Green Dwarf }\end{array}$ & 250 & 245 & 98 \\
Sri Lanka & 27 & 18 & 67 \\
Yellow Dwarf & 22 & 14 & 64 \\
Gon thembili tall & 52 & 20 & 38 \\
\hline King coconut & & &
\end{tabular}


The king coconut form of variety Aurantiaca was observed to be susceptible to the WCLWD. Only $38 \%$ of the evaluated $\mathrm{KC}$ palms were healthy indicating the susceptibility of the majority of $\mathrm{KC}$ palms.

Sri Lanka Tall (SLT), which is the most popular commercial variety, was also highly susceptible (Plate 03) although a smaller percentage of healthy palms (Plate 04) was observed among the severely infected plantations indicating the resistance of individual genotypes of SLT rather than the SLT coconut form as a whole.

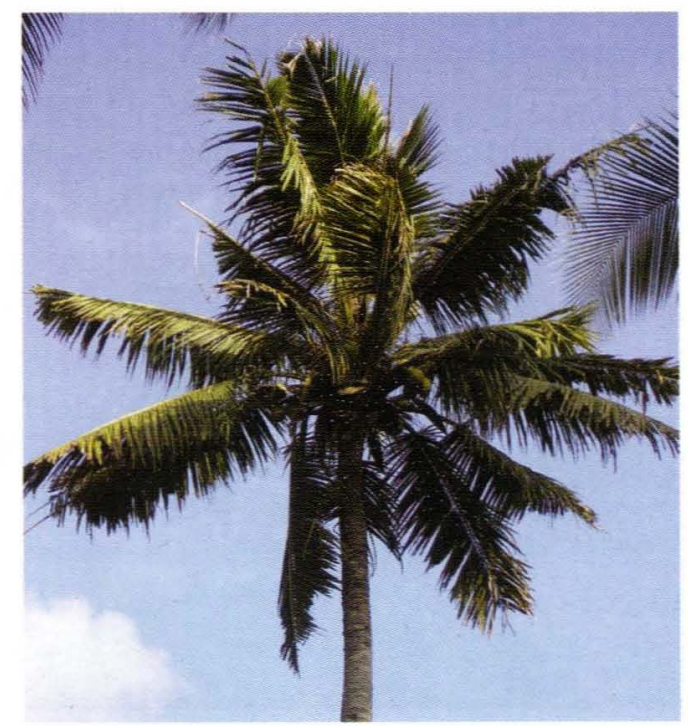

Plate 03: Disease infected Sri Lanka tall palm

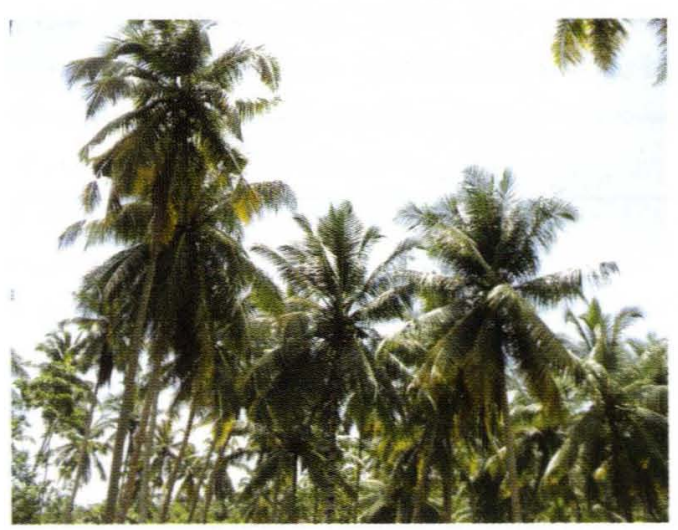

Plate 04: Healthy individual Sri Lanka tall palm amidst diseased palms
The resistance of the Typica variety GTT was higher than that of SLT. Out of a total of 22 individual GTT palms, 14 palms were healthy with a WCLWD resistance of about $63 \%$. In addition to SLT and GTT there were certain other Typica individual genotypes which were healthy. Among them there was one prominent palm resembling the Kamandala form of variety Typica but with reddish brown (rathi) pericarp (Plate 05). It was observed that although the fruit of this coconut phenotype resembled Kamandala the nut within was smaller than typical Kamandala nuts.

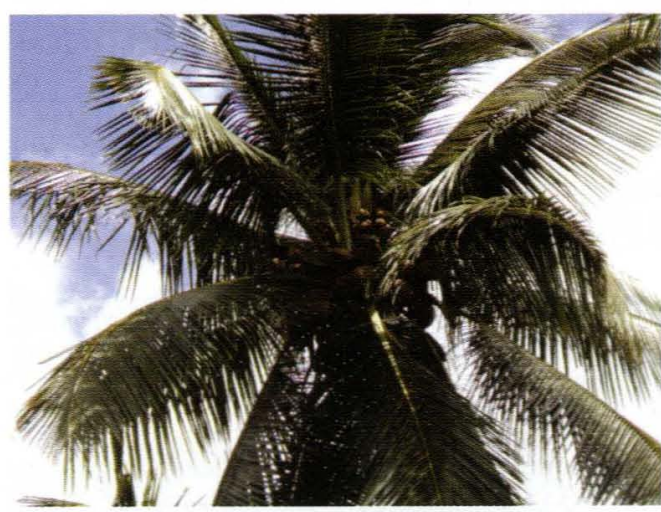

Plate 05: Resistant tall palm (resembling tall form Kamandala)

\section{Genetic governance of WCLWD resistance}

Considering all the different forms of coconut evaluated for resistance to WCLWD only SLGD could be identified as a resistant coconut variety. The mechanism or the mode of resistance of any of these coconut forms is not clear. However, it can be hypothesized that the resistance for WCLWD is under governance of Quantitative Trait Loci (QTL). Dwarf coconuts are predominantly self breeding and therefore they are mostly homozygous purelines. Typica or tall coconuts are naturally out breeding and therefore they are heterogenous populations of varying degrees of heterozygosity. Due to this heterozygosity the progeny of SLT coconuts may segregate to a certain degree. This is even more 
complicated with the out-crossing nature of tall coconuts. However, the situation is different with the dwarf coconuts and therefore resistance may not break down due to segregation because they are mostly inbreeding homozygous lines.

\section{Economic importance of WCLWD resistant SLGD}

SLGD is not a commercially important cultivar in Sri Lanka for culinary purposes or in copra industry, mainly because of the smaller size of the nut. Yet the smaller nut size of SLGD is compensated by the higher number of nuts produced in a bunch. Still, SLGD has commonly been grown in home gardens especially in Southern Sri Lanka for beverage purposes. However with the escalating world demand for coconut as a natural beverage, dwarf coconuts may very well be competitive, not only in the local market but also in the international market. Moreover, the important implication with respect to the genetic improvement of coconut for WCLWD is the presence of genes for resistance and SLGD occupies the top position in the list of resistant varieties. SLGD has been used as a parent in coconut breeding programme in Sri Lanka, for the transfer of genes for precocity and high nut number into commercially more viable tall cultivars since 1960 's. At this point with the coconut breeding objectives expanded to include breeding coconuts for WCLWD, SLGD may prove to be valuable as a donor of WCLWD resistant genes.
The resistance of SLGD to lethal yellowing disease (LYD) which is a deadly disease devastating coconut plantations in the Caribbean and is spreading in Africa has been reported (Quaicoe et al. 2009). LYD is also caused by phytoplasma and therefore it is clear that SLGD is resistant to phytoplasma diseases. Kerala (root) wilt disease that has been present in Kerala, India for the last 150 years, is a phytoplasma disease with similar symptoms to WCLWD (Nair et al. 1996). Chowghat Green dwarf (CGD) coconut in India with similar morphology to SLGD and Malayan Green dwarf have been reported to have a higher degree of resistance to Kerala (root) wilt disease suggesting the resistance of green dwarfs to coconut diseases caused by phytoplasma. Consequently, both these dwarf forms of coconut have been used in the genetic improvement for Kerala (root) wilt disease (Nair et al. 2000). Therefore the study of resistance mechanism of Green dwarf coconut to phytoplasma diseases will be useful in genetic improvement for resistance to phytoplasma diseases and also in other disease management strategies.

\section{ACKNOWLEDGEMENTS}

This work was partly funded by UN-FAO under the FAO-TCP/SRI/3303 project. The authors gratefully acknowledge the assistance and advice from Dr. Priyanthi Fernando, Additional Director/CRI and FAO project National Coordinator and Prof. H. P. M. Gunasena, Chairman of the Coconut Research Board in carrying out this study.

\section{REFERENCES}

Ekanayake G.K., Perera S.A.C.N., Dassanayake P.N. and Everard J.M.D.T. (2010). Varietal classification of new coconut (Cocos nucifera $\mathrm{L}$.) forms identified from Southern Sri Lanka. Cocos:19(1): 41-50

Liyanage D.V. (1958). Varieties and forms of coconut palms grown in Ceylon. Ceylon Coconut Quart. 9(1):1-10 
Nair M.K., Koshy P. K., Nair R.V., Rao E.V.V.B., Nampoothiri K.U.K. and Iyer R. D. (1996). A root (wilt) disease resistant coconut hybrid and strategy for resistance breeding. Indian Coconut J. 27(1): 2-5Nair R.V., Rajesh M.G. and Jacob P.M. (2000). Chowghat Green Dwarf - a suitable variety for the coconut root (wilt) diseased tract. Indian Coconut J. 31(3): 55

Perera L, Meegahakumbura M.K., Wijesekara H.R.T., Fernando W.B.S. and Dickinson M.J. (2012). A Phytoplasma is associated with the Weligama Coconut Leaf Disease in Sri Lanka. J. of Plant Pathol. 94(1):205-209 Quaicoe R., Dery S., Philippe R., Baudouin L., Nipah J., Nkansah Poku, J., Arthur R., Dare D., Yankey E., Pilet F. and Dollet M. (2009). Resistance screening trials on coconut varieties to Cape Saint Paul Wilt Disease in Ghana. OCL VOL. $16 \mathrm{~N}^{\circ} 2$ MARS- AVRIL.

Wijesekara H.T.R., Perera L., Wickramananda I.R., Herath I, Meegahakumbura M.G. M. K., Fernando W.B.S. and de Silva P.H.P.R. (2008). Weligama Coconut Leaf Wilt Disease: A new disease in Southern Sri Lanka. Proceedings of the Plantation second Plantation Crop Research Symposium, BMICH, Colombo, Sri Lanka. A Ninanayake and E Jayamanne (Eds.), Samayawardena printers, Colombo. 